\title{
THE EFFECT OF DIETARY INTAKE AND SOCIAL ECONOMIC FACTORS ON THE RISK OF STUNTING IN PRIMARY SCHOOL CHILDREN IN SURAKARTA, CENTRAL JAVA
}

\author{
Agustina Dwi Utami1), Dono Indarto'), Yulia Lanti Retno Dewi ${ }^{2)}$ \\ ${ }^{1)}$ Masters Program in Public Health, Sebelas Maret University \\ 2)Department of Nutrition, Faculty of Medicine, Sebelas Maret University
}

\begin{abstract}
Background: Globally it was estimated approximately 156 millions (23\%) children are stunted. The prevalence of stunting in children is $29 \%$ in Indonesia, which is the highest rate in South East-Asian countries. Stunting may cause delayed mental development and low intellectual capacity. This study aimed to investigate the effect of dietary intake and social economic factors on the risk of stunting in primary school children in Surakarta, Central Java.

Subjects and Method: This was an analytic observational study using cross-sectional design. The study was conducted in Surakarta, Central Java, from February to March 2017. A sample of 145 primary school children was selected for this study by multi-stage random sampling. The independent variables were energy intake, protein intake, maternal education, maternal employment status, and family income. The dependent variable was stunting. The data were collected by a set of questionnaire and antropometry. The data were analyzed by path analysis.

Results: Stunting was affected by energy intake $(b=0.02 ; \mathrm{SE}<0.01$; $\mathrm{p}<0.001)$, protein intake $(\mathrm{b}=0.02 ; \mathrm{SE}=0.01 ; \mathrm{p}<0.001)$, maternal education $(b=0.23 ; \mathrm{SE}=0.18 ; \mathrm{p}=0.187)$, family income $(\mathrm{b}=0.01 ; \mathrm{SE}=0.01 ; \mathrm{p}=0.051)$. Energy intake was affected by maternal education $(b=9.56 ; \mathrm{SE}=32.55$; $\mathrm{p}=0.770)$, and family income $(\mathrm{b}=1.81 ; \mathrm{SE}=0.91 ; \mathrm{p}=0.005)$. Protein intake was affected by maternal education $(\mathrm{b}=1.75 ; \mathrm{SE}=2.67 ; \mathrm{p}=0.051)$, maternal employment status $(b=-2.30 ; \mathrm{SE}=2.36 ; \mathrm{p}=0.330)$, and family income $(\mathrm{b}=0.12 ; \mathrm{SE}=0.08 ; \mathrm{p}=0.110)$.

Conclusion: Stunting was affected by energy intake, protein intake, maternal education, family income. Energy intake was affected by maternal education and family income. Protein intake was affected by maternal education, maternal employment status, and family income.
\end{abstract}

Keywords: primary shool children, dietary intake, stunting

Correspondence: Agustina Dwi Utami. Masters Program in Public Health, Sebelas Maret University, Jl. Ir. Sutami 36 A, Surakarta 57126, Central Java, Indonesia. Email: agustinadwiutami@gmail.com. Mobile: +6282312719036. 